\title{
Shifts in temperature within the physiologic range modify strand-specific expression of select human microRNAs
}

\author{
RATNAKAR POTLA, ${ }^{1}$ ISHWAR S. SINGH, ${ }^{1,2}$ SERGEI P. ATAMAS, ${ }^{2,3}$ and JEFFREY D. HASDAY ${ }^{1,2}$ \\ ${ }^{1}$ Pulmonary and Critical Care Medicine Division, University of Maryland School of Medicine, Baltimore, Maryland 21201, USA \\ ${ }^{2}$ Medicine and Research Services, Baltimore VA Medical Center, Baltimore, Maryland 21201, USA \\ ${ }^{3}$ Division of Rheumatology and Clinical Immunology, Department of Medicine, University of Maryland School of Medicine, \\ Baltimore, Maryland 21201, USA
}

\begin{abstract}
Previous studies have revealed that clinically relevant changes in temperature modify clinically relevant gene expression profiles through transcriptional regulation. Temperature dependence of post-transcriptional regulation, specifically, through expression of miRNAs has been less studied. We comprehensively analyzed the effect of $24 \mathrm{~h}$ exposure to $32^{\circ} \mathrm{C}$ or $39.5^{\circ} \mathrm{C}$ on miRNA expression profile in primary cultured human small airway epithelial cells (hSAECs) and its impact on expression of a targeted protein, protein kinase $\mathrm{C} \alpha(\mathrm{PKC} \alpha)$. Using microarray, and solution hybridization-based nCounter assays, with confirmation by quantitative RTPCR, we found significant temperature-dependent changes in expression level of only five mature human miRNAs, representing only $1 \%$ of detected miRNAs. Four of these five miRNAs are the less abundant passenger (star) strands. They exhibited a similar pattern of increased expression at $32^{\circ} \mathrm{C}$ and reduced expression at $39.5^{\circ} \mathrm{C}$ relative to $37^{\circ} \mathrm{C}$. As PKC $\alpha$ mRNA has multiple potential binding sites for three of these miRNAs, we analyzed PKC $\alpha$ protein expression in HEK 293T cells and hSAECs. PKC $\alpha$ protein levels were lowest at $32^{\circ} \mathrm{C}$ and highest at $39.5^{\circ} \mathrm{C}$ and specific miRNA inhibitors reduced these effects. Finally, we analyzed cell-cycle progression in hSAECs and found $32^{\circ} \mathrm{C}$ cells exhibited the greatest $\mathrm{G} 1$ to $\mathrm{S}$ transition, a process known to be inhibited by PKC $\alpha$, and the effect was mitigated by specific miRNA inhibitors. These results demonstrate that exposure to clinically relevant hypothermia or hyperthermia modifies expression of a narrow subset of miRNAs and impacts expression of at least one signaling protein involved in multiple important cellular processes.
\end{abstract}

Keywords: microRNA; hyperthermia; hypothermia; lung epithelium

\section{INTRODUCTION}

Human core body temperature is homeostatically maintained within a narrow range (Morrison and Nakamura 2011). The surface-to-core temperature gradient increases during cold exposure, extending to subcutaneous and muscle tissues up to $4 \mathrm{~cm}$ deep (Webb 1992). Core temperature itself can increase by several degrees during fever (Singh and Hasday 2013), exertional/environmental hyperthermia (Leon and Helwig 2010), or as part of adverse drug reactions (Hopkins 2011). A decrease by several degrees may occur during accidental (Reed 1996) or therapeutic hypothermia (The Hypothermia after Cardiac Arrest Study Group 2002; Bernard et al. 2002), sepsis (Clemmer et al. 1992), trauma (Jurkovich et al. 1987), or certain drug intoxications (van Marum et al. 2007; Wilson and Waring 2007). Solid organs harvested for transplantation may be stored at more extreme hypothermia for prolonged periods prior to transplant. Work

\footnotetext{
Corresponding author: jhasday@umaryland.edu

Article published online ahead of print. Article and publication date are at http://www.rnajournal.org/cgi/doi/10.1261/rna.049122.114. Freely available online through the RNA Open Access option.
}

from our group and others has shown that modest changes in temperature within the physiological range alters expression level of certain genes with important physiologic and clinical consequences (Cahill et al. 1996; 1997; Chen et al. 1997, 2006, 2009; Wang et al. 1998; Jiang et al. 1999a,b, 2000; Fairchild et al. 2000; Singh et al. 2000, 2002, 2008; Hasday et al. 2003; Ellis et al. 2005; Appenheimer et al. 2007; Vardam et al. 2007; McClung et al. 2008; Nagarsekar et al. 2008, 2012; Cooper et al. 2010a,b; Lipke et al. 2010, 2011; Fisher et al. 2011; Maity et al. 2011; Tulapurkar et al. 2011, 2012; Shah et al. 2012; Zhang et al. 2012; Gupta et al. 2013). Most of the studies of temperature-dependent gene expression have focused on transcriptional regulation (Cahill et al. 1996, 1997; Chen et al. 1997; Singh et al. 2008; Cooper et al. 2010a,b; Maity et al. 2011; Zhang et al. 2012), but post-transcriptional regulation by small noncoding RNAs like microRNA (miRNA) may be as important as transcriptional regulation for $\sim 30 \%$ of all genes (Lewis et al. 2005).

\footnotetext{
(C) 2015 Potla et al. This article, published in RNA, is available under a Creative Commons License (Attribution 4.0 International), as described at http://creativecommons.org/licenses/by/4.0/.
} 
The classical pathway to generation of mature miRNAs is a stepwise process that progresses from primary transcripts (pri-miRNAs) that fold into imperfect dsRNA-like hairpins by sequential action of two RNase III family nucleases. In the first step, a Class 2 RNase III enzyme Drosha cleaves the sequences $5^{\prime}$ and $3^{\prime}$ to the hairpin structure releasing the $\sim 70 \mathrm{nt}$ pre-miRNA, which contains the mature miRNA duplex within its hairpin structure. The pre-miRNAs are exported to the cytoplasm and incorporated into the RNA-induced Silencing Complex (RISC) where the endonuclease Dicer cleaves the loop structures to yield $\sim 21 \mathrm{nt}$ miRNA duplexes with protruding 2 nt $3^{\prime}$ ends (for review, see Filipowicz et al. 2008). Only one strand of the duplex is retained as the mature miRNA in the RISC and the other is usually degraded (Schwarz et al. 2003). Considering this study is focused on temperature-dependent miRNA expression, it is noteworthy that the strand with the $5^{\prime}$ terminus located at the thermodynamically less-stable end of the duplex is usually retained in the RISC as the mature miRNA (Khvorova et al. 2003).

Based on previous studies showing that transcription of certain mRNAs is temperature-dependent and considering the reported importance of thermodynamics to miRNA strand selection, we hypothesized that changes in temperature within physiological range may also alter expression of certain mature miRNAs, which might have impact on expression of gene products with important potential consequences for homeostasis and disease pathogenesis. We utilized two complementary methods to analyze miRNA expression profiles in primary cultured human small airway epithelial cells (hSAECs) and Human Embryonic Kidney cells (HEK 293T) incubated at $32^{\circ} \mathrm{C}, 37^{\circ} \mathrm{C}$, and $39.5^{\circ} \mathrm{C}$. We confirmed temperature-responsive miRNA expression using quantitative RTPCR, performed an in silico analysis of potential targets of multiple temperature-responsive miRNAs, and analyzed the impact of temperature changes on protein expression of $\mathrm{PKC}$, an important signaling molecule and predicted target of multiple temperature-sensitive miRNAs.

\section{RESULTS}

\section{Mature human miRNA detection by both platforms}

Human SAECs were incubated for $24 \mathrm{~h}$ with or without $1 \mathrm{ng} /$ $\mathrm{mL} \mathrm{TNFa}$ at $32^{\circ} \mathrm{C}, 37^{\circ} \mathrm{C}$, or $39.5^{\circ} \mathrm{C}$ and total RNA was isolated. RNA samples were analyzed for quality by capillary electrophoresis. Samples from four experiments were found to be high quality and were analyzed for miRNA expression profile. RNA samples from all four experiments were analyzed for miRNA profile using the nCounter miRNA assay. Samples from three of these experiments were also analyzed by Affymetrix miRNA microarray. The microarray and nCounter platforms comprised 632 and 811 probe sets, respectively, for mature human miRNAs. The two platforms shared 425 common probe sets. Of the 386 unique miRNAs probed by the nCounter miRNA assay, 64 were detected in at least one sample in all four sample sets. Of the 207 unique miRNAs probed by microarray, 131 were detected in at least one sample in all three sample sets. Of the 425 common miRNAs, 139 were detected by both platforms, 18 of which were detected only by nCounter, and 153 only by microarray. Thus of the 1018 miRNAs probed, 505 (49.6\%) were detected in at least one sample per experiment by one or both assays.

\section{Identification of differentially expressed miRNA}

To model accidental or therapeutic hypothermia or exertional/environmental hyperthermia, hSAECs were exposed to $32^{\circ}$ $\mathrm{C}$ or $39.5^{\circ} \mathrm{C}$, respectively, in the absence of TNFa. To model sepsis-related hypothermia or fever these cells were exposed to $32^{\circ} \mathrm{C}$ or $39.5^{\circ} \mathrm{C}$, respectively, in the presence of $1 \mathrm{ng} / \mathrm{mL}$ $\mathrm{TNF}$, a proinflammatory cytokine that plays a central role in the pathogenesis of sepsis (Qiu et al. 2011). Of the 505 miRNAs detected in hSAECs, only 11 were differentially expressed in cells incubated for $24 \mathrm{~h}$ at $32^{\circ} \mathrm{C}$ and/or $39.5^{\circ} \mathrm{C}$ with or without TNFa (Table 1; Fig. 1A). Of these, 10 were detected by microarray and one was detected by nCounter. Seven of the temperature-responsive miRNAs that were detected by microarray were not included in the nCounter probe set. The other three miRNAs found to be temperature-responsive by microarray, hsa-miR-3195, hsa-miR-1468, and hsa-miR564 , were present in the nCounter probe set but were not detected in any of the samples by nCounter assay and were not included in the subsequent analysis. For hsa-miR-18b, the temperature-response pattern was different in the presence or absence of TNFa. Without TNFa, hsa-miR-18b expression levels were reduced at both $32^{\circ} \mathrm{C}$ and $39.5^{\circ} \mathrm{C}$ compared with $37^{\circ} \mathrm{C}$, but when the hSAECs were treated with TNFa, miR-18b expression levels were higher at both $32^{\circ} \mathrm{C}$ and $39.5^{\circ} \mathrm{C}$ compared with $37^{\circ} \mathrm{C}$. For the other six temperatureresponsive miRNAs identified by microarray, the temperature-response pattern was unaffected by the presence or absence of TNFa. Four of these miRNAs, hsa-miR-181a-3p, hsa-miR-27a-5p, hsa-miR-27b-5p, and hsa-miR-92a-1-5p, exhibited a similar expression pattern with highest expression at $32^{\circ} \mathrm{C}$ and lowest at $39.5^{\circ} \mathrm{C}$. For the other two miRNAs, hsamiR-380-5p and hsa-miR-3188, gene expression was lower at both $32^{\circ} \mathrm{C}$ and $39.5^{\circ} \mathrm{C}$ than at $37^{\circ} \mathrm{C}$ (Fig. 1B,C). The only temperature-responsive miRNA detected exclusively by the nCounter miRNA assay, miR-1260a, exhibited a temperature-response pattern similar to miR-181a, and two-way ANOVA analysis showed there was no effect of TNFa.

\section{Confirmation of selected miRNA by quantitative PCR}

The six miRNAs (hsa-miR-18b, hsa-miR-27a-5p, hsamiR-27b-5p, hsa-miR-92a-1-5p, hsa-miR-181a-3p, and hsa-miR-1260a) shown to exhibit consistent patterns of temperature-dependent expression by microarray and nCounter assays were further analyzed by qRT-PCR. Five of these miRNAs (hsa-miR-27b-5p, hsa-miR-92a-1-5p, hsa- 
TABLE 1. Microarray analysis of the effect of incubation temperature on expression levels of pre- and mature miRNAs

\begin{tabular}{|c|c|c|c|c|c|c|c|c|c|c|}
\hline \multirow[b]{3}{*}{ miRNA } & \multicolumn{5}{|c|}{ Mature miRNA (fold versus $37^{\circ} \mathrm{C}$ ) } & \multicolumn{5}{|c|}{ Pre-miRNA (fold versus $37^{\circ} \mathrm{C}$ ) } \\
\hline & \multicolumn{2}{|c|}{ No TNF $\alpha$} & \multicolumn{2}{|c|}{ With TNF $\alpha$} & \multirow[t]{2}{*}{ ANOVA $P$-value } & \multicolumn{2}{|c|}{ No TNF $\alpha$} & \multicolumn{2}{|c|}{ With TNF $\alpha$} & \multirow[t]{2}{*}{ ANOVA $P$-value } \\
\hline & $32^{\circ} \mathrm{C}$ & $39.5^{\circ} \mathrm{C}$ & $32^{\circ} \mathrm{C}$ & $39.5^{\circ} \mathrm{C}$ & & $32^{\circ} \mathrm{C}$ & $39.5^{\circ} \mathrm{C}$ & $32^{\circ} \mathrm{C}$ & $39.5^{\circ} \mathrm{C}$ & \\
\hline $181 a-3 p^{a}$ & 2.22 & 1.56 & 1.67 & 0.64 & $2 \times 10^{-5}$ & 1.0 & 0.83 & 0.7861 & 0.8102 & 0.5312 \\
\hline $27 a-5 p^{a}$ & 2.21 & 0.84 & 3.90 & 0.82 & 0.0009 & 1.09 & 1.01 & 1.474 & 1.1327 & 0.0912 \\
\hline $27 b-5 p^{a}$ & 3.78 & 0.47 & 2.15 & 0.41 & 0.0006 & 1.09 & 1.01 & 1.474 & 1.1327 & 0.0912 \\
\hline $92 a-1-5 p^{a}$ & 2.19 & 0.68 & 2.03 & 0.64 & 0.0045 & 1.43 & 0.78 & 1.1408 & 1.0352 & 0.3978 \\
\hline $380-5 p^{a}$ & 1.03 & 0.90 & 1.28 & 0.85 & 0.0419 & 0.86 & 0.84 & 1.1685 & 0.9696 & 0.3553 \\
\hline $18 b^{a}$ & 1.75 & 1.43 & 1.48 & 2.42 & 0.0262 & 0.90 & 0.98 & 0.7922 & 0.8629 & 0.4997 \\
\hline $3188^{a}$ & 1.16 & 0.62 & 0.94 & 1.11 & 0.0173 & $N P^{d}$ & NP & NP & NP & NP \\
\hline $3195^{\mathrm{a}, \mathrm{b}}$ & 1.77 & 0.90 & 1.12 & 0.65 & 0.0069 & NP & NP & NP & NP & NP \\
\hline $1468^{a, b}$ & 0.92 & 1.17 & 0.99 & 0.98 & 0.0024 & NP & NP & NP & NP & NP \\
\hline $564^{a, b}$ & 1.15 & 0.89 & 1.20 & 1.01 & 0.0121 & 1.15 & 0.96 & 0.94 & 0.89 & 0.4474 \\
\hline $1260 a^{c}$ & 2.35 & 0.95 & 2.12 & 0.84 & 0.028 & 1.39 & 0.78 & 0.90 & 1.16 & 0.1908 \\
\hline
\end{tabular}

${ }^{a}$ All pre-miRNAs and indicated mature miRNAs measured by microarray.

${ }^{b}$ Indicated mature miRNAs also measured by nCounter (fold-change values are from microarray).

"Mature 1260a measured only by nCounter.

dPre-miRNA not present in probe set.

miR-27a-5p, hsa-miR-181a-3p, and hsamiR-1260a) showed similar patterns of temperature-responsiveness by qRTPCR and microarray or NCounter analysis (Fig. 2A-E). The identities of each qRT-PCR product were confirmed to be the miRNA of interest by cloning and sequencing; the chromatograms for each are shown in Figure 2. The absolute expression level of each of the five temperature-responsive miRNAs was estimated from the Nanostring data and is shown on the right-hand $y$-axis in the Figure 2A-E. The temperature-responsiveness demonstrated for hsa-miR-18b by microarray was not confirmed by qRTPCR (Fig. 2F). Four of these confirmed miRNAs represent the star strand, which is accepted as the less abundant strand for the corresponding mature miRNA duplex (Schwarz et al. 2003).

Levels of the opposite miRNA strand and corresponding long form stem-loop precursors (pre-miRNA), and primary transcripts (pri-miRNA) for four of the five confirmed temperature-responsive miRNAs were quantified by qRT-PCR (Fig. 3). A similar analysis of hsa-miR1260a was not possible as its premiRNA sequence is embedded in exon 3 of the neuroglobin gene and its $3 p$ arm has not yet been defined. The corresponding opposite strands, the pre-, and pri-forms for three of these miRNAs,
A
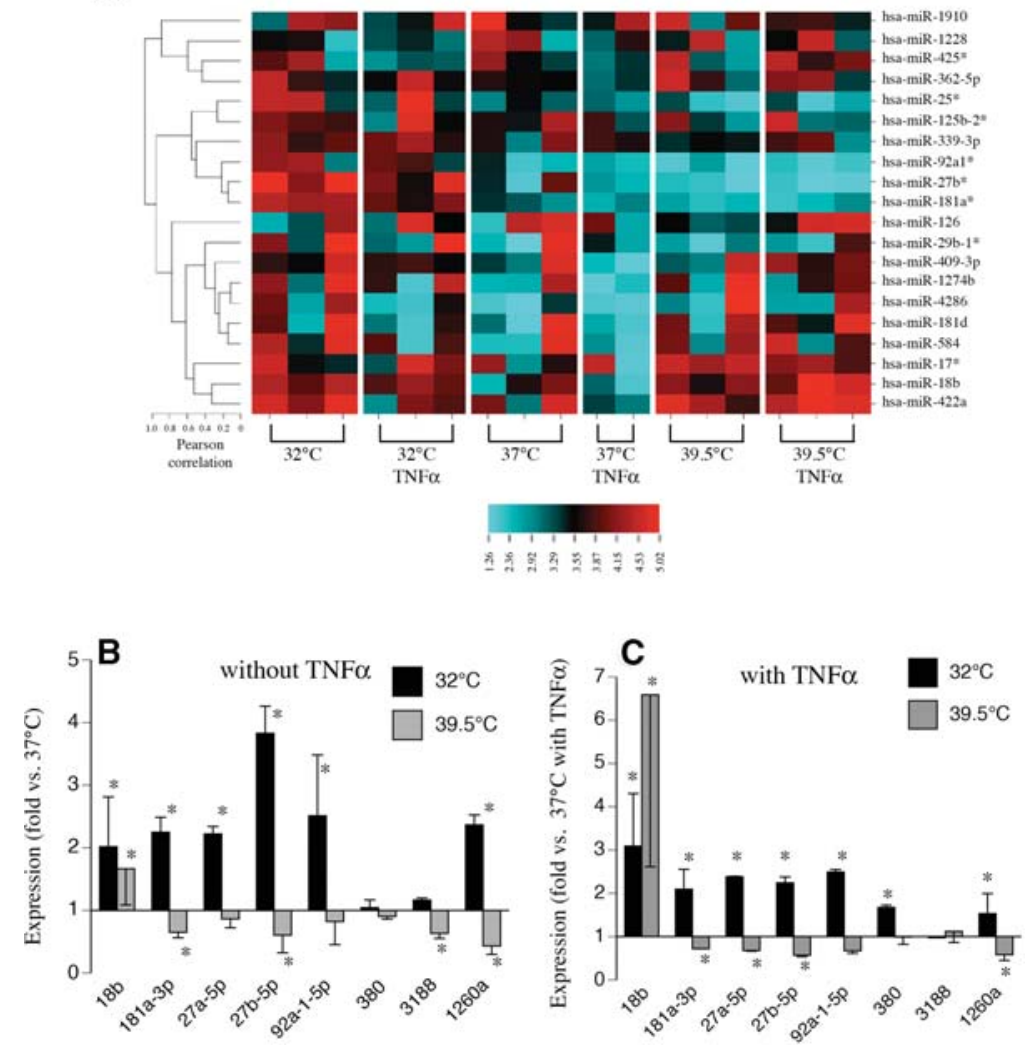

FIGURE 1. Microarray and nCounter analysis of the effects of incubation temperature on miRNA expression pattern in human SAECs. (A) HEATMAP of selected miRNAs detected by microarray in hSAECs following $24 \mathrm{~h}$ incubation at $32^{\circ} \mathrm{C}, 37^{\circ} \mathrm{C}$, or $39.5^{\circ} \mathrm{C}$ in the absence or presence of $1 \mathrm{ng} / \mathrm{mL}$ rhTNFa. $(B, C)$ Microarray data for seven miRNAs exhibiting temperature-dependent expression and nCounter data for miR1260a expression expressed as fold-change versus $37^{\circ} \mathrm{C}$ cells in the absence $(B)$ or presence $(C)$ of TNFa. Mean \pm SEM. $\left(^{*}\right) P<0.01$ versus $37^{\circ} \mathrm{C} . N=$ 3 for microarray and 4 for nCounter. 

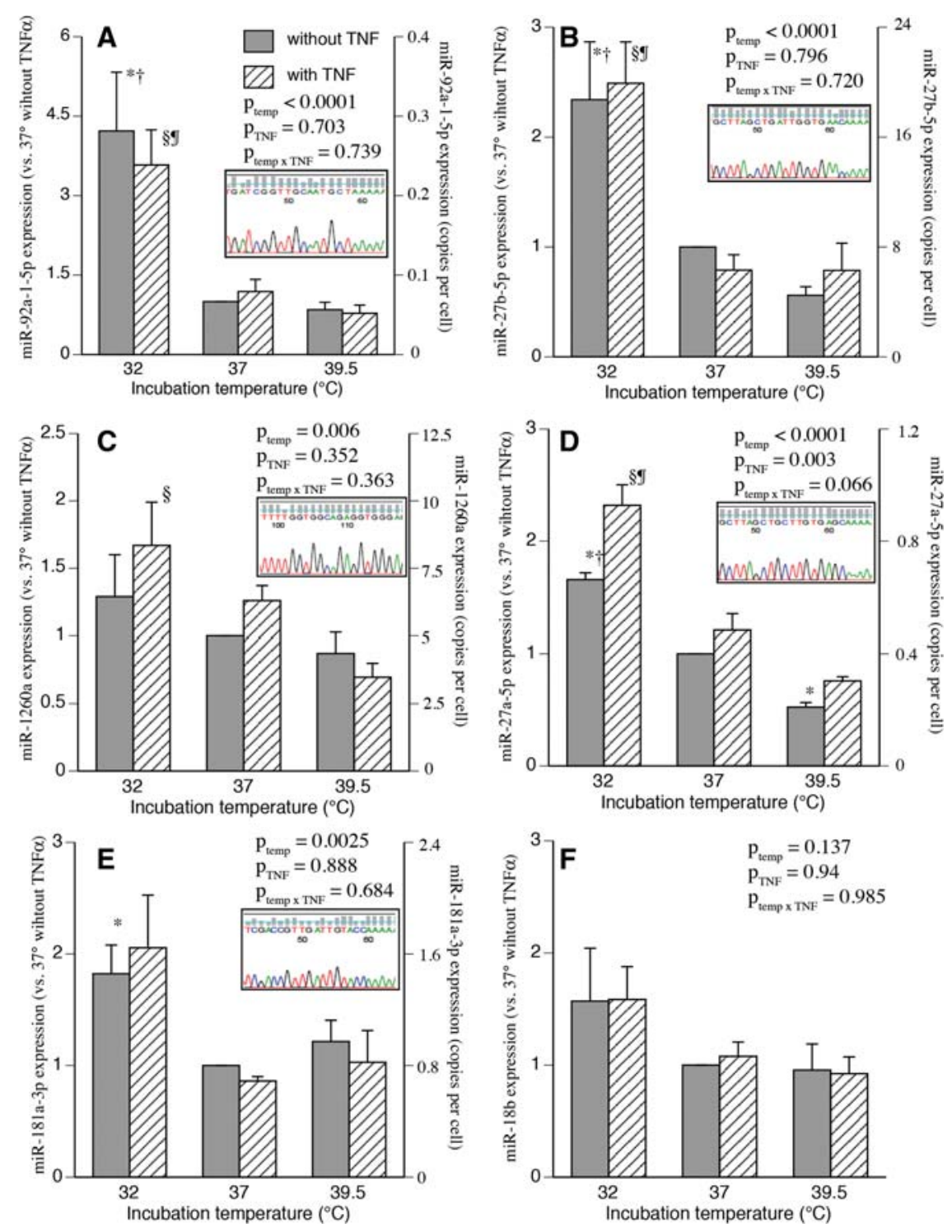

FIGURE 2. Quantitative RT-PCR confirmation of temperature effects on miRNA expression pattern in human SAECs. Human SAECs from two lots were incubated for $24 \mathrm{~h}$ at $32^{\circ} \mathrm{C}, 37^{\circ} \mathrm{C}$, or $39.5^{\circ} \mathrm{C}$ without or with $1 \mathrm{ng} / \mathrm{mL}$ rhTNFa. Total RNA was collected and levels $(A)$ hsa-miR92a-1-5p, (B) hsa-miR-27b-5p, (C) hsa-miR-1260a, $(D)$ hsa-miR-27a-5p, (E) hsa-miR-181a$3 \mathrm{p}$, and $(F)$ hsa-miR-18b were analyzed by qRT-PCR as described in Materials and Methods and expressed as a fold-change versus $37^{\circ} \mathrm{C}$ cells without TNFa. The right-hand axis displays the total expression level in copies per cell, which was calculated as described in Materials and Methods. Mean \pm SEM. (*) $P<0.05$ versus $37^{\circ} \mathrm{C}$; (†) $P<0.05$ versus $39.5^{\circ} \mathrm{C}$; (\$) $P<0.05$ versus $37^{\circ} \mathrm{C}$ with TNFa; ( $) P<0.05$ versus $39.5^{\circ} \mathrm{C}$ with $\mathrm{TNFa}, n=4$. The temperature-responsive miRNAs were cloned into $\mathrm{T}$-Vector and sequenced (inset).

hsa-miR-92a-3p, hsa-miR-27b-3p, and hsa-miR-27a-3p, were not affected by either temperature change (Fig. 3A-C) or TNFa treatment (data not shown). In contrast, for hsamiR-181a-5p, expression levels of both mature strands, preand pri-forms tended to be higher at both $32^{\circ} \mathrm{C}$ and $39.5^{\circ} \mathrm{C}$ compared with $37^{\circ} \mathrm{C}$ (Fig. 3D). In addition, pre-miRNA forms for three of the temperature-sensitive miRNAs, hsamiR-92a, hsa-miR-27a, and hsa-miR-1260a, were included in the microarray probe set and shown to have similar expression levels at all three temperatures (Table 1).

\section{Thermodynamic properties of temperature-responsive miRNAs}

We analyzed the mature miRNA duplexes corresponding to four of the five temperature-responsive miRNAs for predicted overall duplex stability, the stability of each end of the duplex, the asymmetry of stability between ends of each duplex, and its relationship to the mature temperature-responsive miRNA strand. We compared each of the temperature-responsive miRNAs with the other nontemperature-responsive miRNAs from the same cluster, which were identified using mIRBase (Table 2; Kozomara and Griffiths-Jones 2014). A similar analysis of hsa-miR-1260a was not possible because its p-arm has not been unambiguously identified. Hsa-miR-27a and hsa-miR$27 \mathrm{~b}$ were the most stable miRNAs in their respective clusters and hsa-miR-92a-1 was the second most stable of six miRNAs in its cluster. There was only one other miRNA in the hsa-miR-181a1 cluster, hsa-miR-181b-1, and both miRNAs had the same predicted free energy. Three of the four temperatureresponsive miRNAs exhibited the greatest asymmetry in predicted stability between duplex ends within their cluster. Interestingly, all four of the temperatureresponsive miRNAs were derived from the strand with greater duplex stability at its $5^{\prime}$ end and, therefore, predicted to be the less abundant or star strand (Khvorova et al. 2003).

\section{Target prediction and validation}

Potential gene targets of the temperatureresponsive miRNAs were identified using the miRTar algorithm (Hsu et al. 2011). Three of the five miRNAs, hsa-miR92a-1-5p, hsa-miR-27b-5p, and hsamiR-1260a, were predicted to target the PRKCA gene encoding $\mathrm{PKC} \alpha$, an important signaling molecule. To determine whether the observed temperature-responsive changes in miRNA expression are biologically relevant and impact expression levels of target protein, we analyzed the effects of hypo- and hyperthermia on PKCa protein levels in hSAECs (Fig. 4A) and HEK 293T cells (Fig. 4B) by Western blotting. Compared with $37^{\circ} \mathrm{C}$ HEK $293 \mathrm{~T}$ cell cultures, levels of PKCa were $37 \%$ lower in cells incubated at $32^{\circ} \mathrm{C}$ for $24 \mathrm{~h}$ and $35 \%$ higher in cells incubated at $39.5^{\circ} \mathrm{C}$. Human SAECs exhibited 

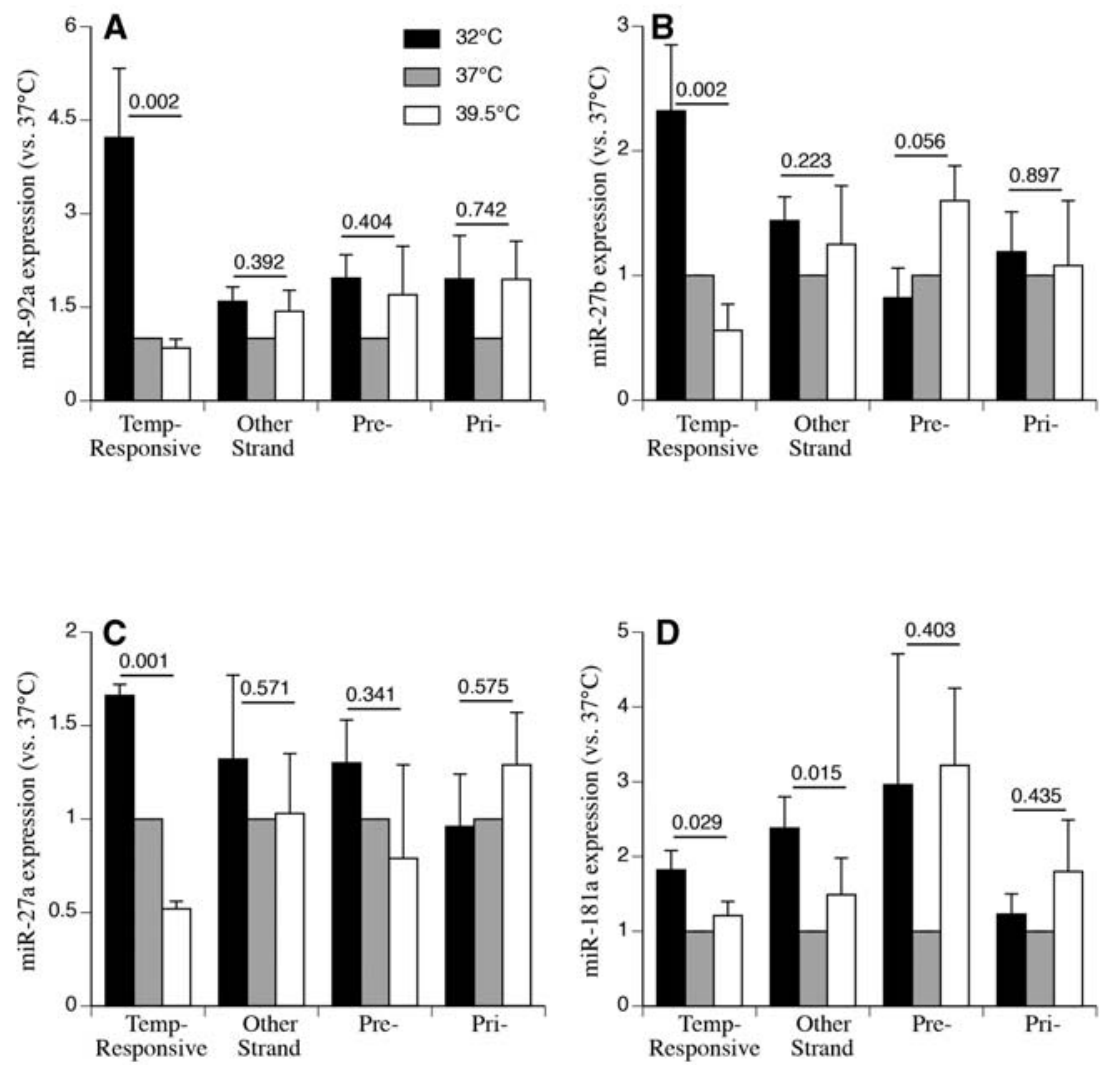

FIGURE 3. Quantitative RT-PCR analysis of temperature effects on pri-miRNA, pre-miRNA, and opposite strand expression pattern in human SAECs. Human SAECs from two lots were incubated for $24 \mathrm{~h}$ at $32^{\circ} \mathrm{C}, 37^{\circ} \mathrm{C}$, or $39.5^{\circ} \mathrm{C}$ without rhTNFa. Total RNA was collected and levels of the temperature-responsive strand, the sister strand, the pri-miRNA, and the pre-miRNA for $(A)$ hsa-miR-92a-1, $(B)$ hsa-miR-27b, $(C)$ hsa-miR-27a, and $(D)$ hsa-miR-181a were analyzed by qRT-PCR as described in Materials and Methods and are expressed relative to expression of each in $37^{\circ} \mathrm{C}$ hSEAECs. Mean $\pm \mathrm{SEM}, n=4$. The $P$-values from one-way ANOVA are indicated.

a similar pattern of temperature-dependent PKCa protein expression as the HEK 293T cells. To determine the potential contribution of the hypothermia-induced miRNAs to changes in PKCa protein levels, we pre-loaded HEK 293T cells with miRNA inhibitors against hsa-miR-92a-1-5p, hsa-miR-27b$5 \mathrm{p}$, and hsa-miR-1260a for $24 \mathrm{~h}$ prior to a $24 \mathrm{~h}$-exposure to $32^{\circ} \mathrm{C}, 37^{\circ} \mathrm{C}$, or $39.5^{\circ} \mathrm{C}$ followed by Western blot analysis of PKCa protein levels (Fig. 4B). Cells that were preloaded with these three miRNA inhibitors increased PKCa levels at all three temperatures with the greatest increase occurring in the cells incubated at $32^{\circ} \mathrm{C}$.

To further demonstrate the specificity of hsa-miR-92a-15p, hsa-miR-27b-5p, and hsa-miR-1260a for the PKCa $3^{\prime}$ UTR, multiple potential binding sites for these three miRNAs were identified in the $3^{\prime}$ UTR of PRKCA gene using PITA (Kertesz et al. 2007) and incorporated into pmirGLO dual luciferase miRNA reporter plasmid (Fig. 5A,B). pmirGLO-PKCa-WT contained three binding sites each for hsa-miR-92a-1-5p and hsa-miR-27b-5p and one binding site for hsa-miR-1260a and pmirGLO-PKCa-Mut contained an identical sequence except inactivating mutations were in- troduced into each of the putative miRNA binding sequences. HEK 293T cells were transfected with miRNA mimics for hsa-miR-92a-1-5p, hsa-miR-27b$5 \mathrm{p}$, and hsa-miR-1260a or with scrambled mimic and with pmirGLO-aPKCaWT or pmirGLO-PKCa-Mut and were lysed and analyzed for luciferase activities $48 \mathrm{~h}$ later (Fig. 5C). The miRNA mimics reduced firefly luciferase levels in cells transfected with pmirGLO-PKCa-WT by $49.5 \%$ compared with scrambled mimic. In contrast, the miRNA mimics had no effect on luciferase levels in cells transfected with pmirGLO-PKCa-Mut.

\section{Downstream biological consequences for changes in temperature}

To understand the potential biological impact of altered PKCa protein levels, we analyzed cell-cycle progression in growth-factor starved hSAECs incubated for $24 \mathrm{~h}$ at $32^{\circ} \mathrm{C}, 37^{\circ} \mathrm{C}$, and $39.5^{\circ} \mathrm{C}$ in serum-containing growth medium (Fig. 6A). Human SAECs incubated at $32^{\circ} \mathrm{C} \mathrm{ex}-$ hibited relatively fewer cells in G1 phase and more cells in $\mathrm{S}$ phase compared with $37^{\circ} \mathrm{C}$ and $39.5^{\circ} \mathrm{C}$ cells. To evaluate the contribution of the temperature-responsive PKCa-targeting miRNAs, we transfected HEK 293T cells with miRNA inhibitors against hsa-miR-92a-1-5p, hsa-miR-27b-5p, and hsa-miR-1260a 24 h prior to growth factor starvation at $32^{\circ} \mathrm{C}$ or $37^{\circ} \mathrm{C}$, then replaced the medium with serum-containing growth medium for an additional 24 h (Fig. 6B). As we found for hSAECs, the G1:S ratio was lower in HEK $293 \mathrm{~T}$ incubated at $32^{\circ} \mathrm{C}$ cells than in $37^{\circ} \mathrm{C}$ cells. Importantly, the temperature-dependent difference was reduced by pretreating $32^{\circ} \mathrm{C}$ cells with miRNA inhibitors.

\section{DISCUSSION}

Deviations from the normal core temperature range may have important consequences for health and disease (Hasday 1996; Hasday et al. 2011; Shah and Hasday 2012; Singh and Hasday 2013). Although hypothermia is generally considered to be anti-inflammatory and pro-survival (Beilin et al. 1998; The Hypothermia after Cardiac Arrest Study Group 2002; Ning et al. 2002; Shankaran et al. 2005), moderate hypothermia can prolong TNF $\alpha$ and IL- $1 \beta$ expression (Fairchild et al. 2004, 2005), and increase expression of CD14 (Sonna et al. 2006) in mononuclear phagocytes. While moderate hyperthermia is usually considered pro-inflammatory (Ostberg 
TABLE 2. Thermodynamic properties of temperature-responsive miRNAs and their cluster mates

\begin{tabular}{|c|c|c|c|c|c|}
\hline \multirow[b]{2}{*}{ miRNA } & \multicolumn{3}{|c|}{$\begin{array}{c}\text { Free energy at } 37^{\circ} \mathrm{C} \\
(\mathrm{kcal} / \mathrm{mol})\end{array}$} & \multirow{2}{*}{$\begin{array}{c}5 p-3 p \\
\text { absolute } \\
\text { difference }^{c}\end{array}$} & \multirow{2}{*}{$\begin{array}{c}\text { Less } \\
\text { stable } \\
\text { end }\end{array}$} \\
\hline & Total & $5 p$ end $^{a, b}$ & $3 p$ end $^{a, b}$ & & \\
\hline hsa-miR-27a ${ }^{d}$ & -22 & -7.9 & -6.6 & 1.3 & $3 p$ \\
\hline hsa-miR-23a & -20.9 & -5.4 & -5.7 & 0.3 & $5 p$ \\
\hline hsa-miR-24-2 & -18.5 & -4.1 & -4.4 & 0.3 & $5 p$ \\
\hline hsa-miR-27b & -18.9 & -9.8 & -6.0 & 3.8 & $3 p$ \\
\hline hsa-miR-23b & -18.6 & -3.1 & -3.4 & 0.3 & $5 p$ \\
\hline hsa-miR-3074 & -17.0 & -3.2 & -2.3 & 0.9 & $3 p$ \\
\hline hsa-miR-24-1 & -15.9 & -4.1 & -1.8 & 2.3 & $3 p$ \\
\hline hsa-miR-181a-1 & -17.8 & -5.4 & -9.0 & 3.6 & $5 p$ \\
\hline hsa-miR-181b-1 & -17.8 & -6.0 & -8.7 & 2.7 & $5 p$ \\
\hline hsa-miR-92a-1 & -23.8 & -9.0 & -7.8 & 1.2 & $3 p$ \\
\hline hsa-miR-17 & -22.1 & -5.2 & -13.4 & 8.2 & $5 p$ \\
\hline hsa-miR-18a & -17.8 & -6.0 & -8.7 & 2.7 & $5 p$ \\
\hline hsa-miR-19a & -23.5 & -7.1 & -9.7 & 2.6 & $5 p$ \\
\hline hsa-miR-20a & -26.6 & -5.2 & -13.4 & 8.2 & $5 p$ \\
\hline hsa-miR-19b-1 & -19.7 & -7.1 & -8.6 & 1.5 & $5 p$ \\
\hline
\end{tabular}

${ }^{a}$ Refers to duplex end containing $5^{\prime}$ terminus of $5 p$ and $3 p$ arm, respectively.

${ }^{\mathrm{b}}$ Calculated as the difference between total unconstrained miRNA free energy and the free energy when the 5 terminal nucleotides of the $5 p$ or $3 p$ end are forced to be unpaired.

${ }^{\mathrm{c}}$ The absolute difference between free energy of the $5 p$ and $3 p$ ends were calculated as a measure of duplex asymmetry.

${ }^{\mathrm{d}}$ The temperature-responsive miRNAs are bolded and the other members of the cluster listed below.

et al. 2000, 2001; Hasday et al. 2003; Rice et al. 2005; Lipke et al. 2010, 2011), moderate hyperthermia reduces expression of TNFa (Singh et al. 2002; Cooper et al. 2010a,b), G-CSF (Zhang 2011), IL-1 $\beta$ (Cahill et al. 1996, 1997; Xie and Calderwood 2001; Xie et al. 2002), c-fos (Xie et al. 2003), and IL18 (Wang et al. 2010). Our previous studies have demonstrated that modest deviations from normothermia can alter stressinduced and proinflammatory signaling pathways, including heat shock factor-1 (HSF-1), p38 MAP kinase, and NFkB (Fairchild et al. 2004, 2005; Tulapurkar et al. 2009, 2012; Shah et al. 2012) and modify expression of important genes. We have previously identified several mechanisms by which shifts in temperature within the physiologic range modify gene transcription (Singh et al. 2002, 2008; Cooper et al. 2010a, b). In this paper, we have expanded these studies by analyzing how shifts in temperature within the clinical range modify expression of a discrete subset of miRNAs and evaluating the consequences for post-transcriptional regulation, the effects on protein expression of an important predicted miRNA target, $\mathrm{PKC} \alpha$, and the impact on cell proliferation.

As the primary cultured hSAECs used in this study are isolated from airways that are $\leq 1 \mathrm{~mm}$ in diameter and close to core temperature in vivo (McFadden and Pichurko 1985), the in vitro exposure temperatures used in this study are similar to the temperatures these cells experience in vivo during clinically relevant hypothermic, normothermic, and hy- perthermic states. The following four comparison groups were studied to simulate clinically relevant conditions: hypothermia $\left(32^{\circ} \mathrm{C}\right.$ versus $\left.37^{\circ} \mathrm{C}\right)$, hyperthermia $\left(39.5^{\circ} \mathrm{C}\right.$ versus $\left.37^{\circ} \mathrm{C}\right)$, therapeutic hypothermia $\left(32^{\circ} \mathrm{C}\right.$ with $\mathrm{TNF} \alpha$ versus $37^{\circ} \mathrm{C}$ with $\mathrm{TNF} \alpha$ ), and fever $\left(39.5^{\circ} \mathrm{C}\right.$ with $\mathrm{TNF} \alpha$ versus $37^{\circ} \mathrm{C}$ with $\mathrm{TNFa}$ ). Microarray and Nanostring assays with confirmation by qRT-PCR identified only 5 (1\%) of 505 miRNAs detected in hSAECs that exhibited temperature-dependent expression and this pattern was not influenced by the presence of TNFa.

Billeter et al. (2012) analyzed miRNA expression in ex vivo whole human blood stimulated with low dose $(1 \mathrm{ng} / \mathrm{mL})$ LPS using microarray and found only $3 \%$ of screened miRNAs showed temp-responsiveness to temperature

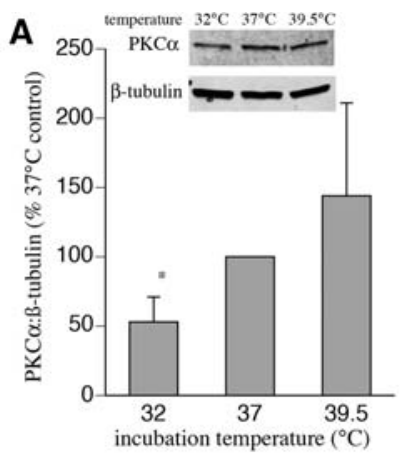

B
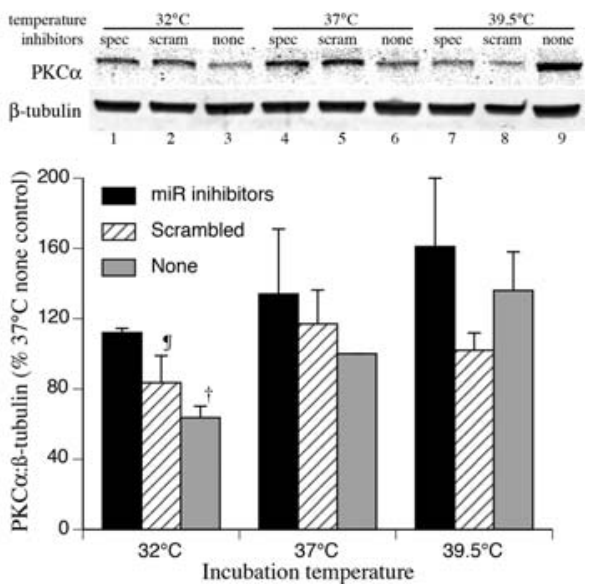

FIGURE 4. Clinically relevant temperature change-induced expression of miRNAs alters the PKCa protein levels. (A) Human SAECs were incubated at $32^{\circ} \mathrm{C}, 37^{\circ} \mathrm{C}$, or $39.5^{\circ} \mathrm{C}$ for $24 \mathrm{~h}$ and cell lysates were immunoblotted for PKCa. Representative of four similar blots and quantified band densities for PKCa normalized to $\beta$-tubulin and expressed as percent of levels in $37^{\circ} \mathrm{C}$ cells. (B) HEK $293 \mathrm{~T}$ cells were transfected either with a combination of miRNA inhibitors against hsa-miR-27b-5p, hsa-miR-1260a, and hsa-miR-92a-1-5p or an equal concentration of a non-targeting scrambled-sequence inhibitor control. Transfected and untransfected cells were incubated at $32^{\circ} \mathrm{C}, 37^{\circ} \mathrm{C}$, or $39.5^{\circ} \mathrm{C}$ for $24 \mathrm{~h}$ and immunoblotted for PKCa. A representative immunoblot and quantified band densities from four similar blots normalized to B-tubulin and expressed as percent of levels in untreated $37^{\circ} \mathrm{C}$ cells are shown. Mean \pm SEM. ( $\left.{ }^{*}\right) P<0.05$, (†) $P<0.04$ versus untreated $37^{\circ} \mathrm{C}$ and $39.5^{\circ} \mathrm{C}$ cells and miRNA inhibitor-treated $32^{\circ} \mathrm{C}$ cells, $(\uparrow) P<0.02$ versus untreated $39.5^{\circ} \mathrm{C}$ cells; $n=4$. 


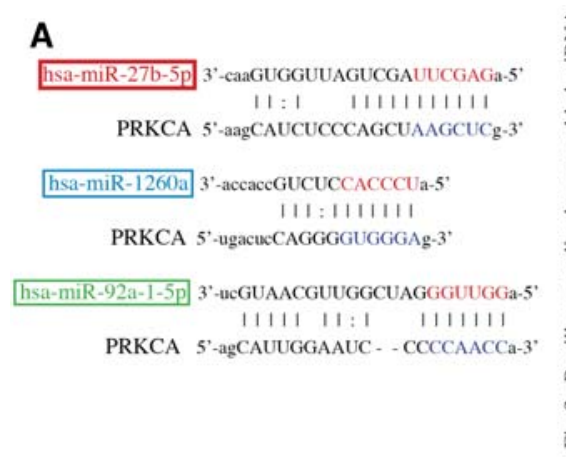

B

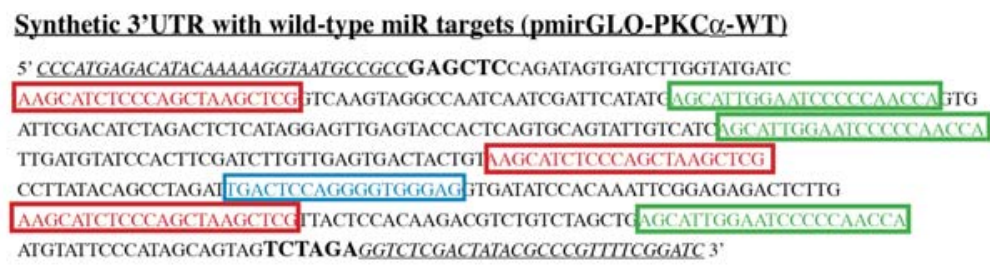

Synthetic 3'UTR with mutated miR targets (pmirGLO-PKC $\alpha$-Mut) 5 . CCCATGAGACATACAAAAAGGTAATGCCGCCGAGCTCCAGATAGTGATCTTGGTATGATC MAGICATCTCCCAGCTAAGGAGG GTCAAGTAGGCCAATCAATCGATTCATATC AGCATTGGAATCCCCCATGGAGTG ATTCGACATCTAGACTCTCATAGGAGTTGAGTACCACTCAGTGCAGTATTGTCATC $\triangle G C A T T G G A A T C C C C C A T G G N$ TTGATGTATCCACTTCGATCTTGTTGAGTGACTACTGI AGCATCTCCCAGCTAAGGAG CCTTATACAGCCTAGA1 [GACTCCAGGGGTGCCTG JTGATATCCACAAATTCGGAGAGACTCTTG AAGCATCTCCCAGCTAAGGAGG TACTCCACAAGACGTCTGTCTAGCTC AGCATTGGAATCCCCCATGGA ATGTATTCCCATAGCAGTAGTCTAGAGGTCTCGACTATACGCCCGTTTCGGATC 3 .

FIGURE 5. Functional analysis of the PKCa $3^{\prime}$ UTR binding sites for the temperature-sensitive miRNAs. (A) The putative binding sequences for hsa-miR-27b-5p, hsa-miR-1260a, and hsamiR-92a-1-5p in PKCa 3' UTR are shown. (B) Sequence of pmirGLO-PKCa-WT or pmirGLO-PKCa-Mut generated by cloning repeats of the putative miR binding sites or mutated sequences, respectively, into pmirGLO. The mutated nucleotides in each miR target sequence is indicated by black text for pmirGLO-PKCa-Mut. (C) HEK 293T cells were transfected with a combination of synthetic miRNA mimics for hsa-miR-27b-5p, hsa-miR-1260a, and hsa-miR92a-1-5p or an equal concentration of non-targeting scrambled control mimic and pmirGLOPKCa-WT (wild-type) or pmirGLO-PKCa-Mut (mutant), incubated at $37^{\circ} \mathrm{C}$ for $24 \mathrm{~h}$, and dual luciferase assays were performed. Mean \pm SEM. $\left({ }^{*}\right) P<0.05, n=4$.

changes between $34^{\circ} \mathrm{C}$ and $40^{\circ} \mathrm{C}$. One of these was hsamiR181a, which demonstrated a similar pattern to its expression in hSAECs, was increased in hypothermic cells and reduced in hyperthermic cells. Truettner et al. (2011) analyzed the effect of $4 \mathrm{~h}$ exposure to hypothermia or hyperthermia on miRNA expression in brain in a rat traumatic brain injury model. They found that post-trauma brain levels of miR-27b were higher in rats exposed to hypothermia than in normothermic rats. While these two studies showed similar effects of temperature shifts on expression of miR$181 \mathrm{a}$ and miR-27b as found in our current study, these authors did not consider whether the temperature-responsive miRNAs were the $3 \mathrm{p}$ - or $5 \mathrm{p}$-arm. Nonetheless, these two studies and the results of our current study demonstrate that clinically relevant hypothermic temperatures induce expression of surprisingly few miRNA genes.

In our current study, miRNAs were profiled using two assay platforms that had significant overlap in the miRNAs probed but with important differences. While the Affymetrix microarray contains probe sets for both precursor and mature miRNA, the nCounter solution hybridization assay only contains probe sets for mature miRNA. The microarray includes probe sets for both strands of most mature miRNAs, while the nCounter probe sets are biased toward the more abundant (guide) strand of mature miRNA and probe for few star (less abundant "passenger") strands. As most of the temperature-sensitive miRNAs detected by microarray were the star strands, these miRNAs would be largely undetectable by the nCounter probe set. None of the miRNAs that were detected by both platforms exhibited temperature-sensitive expression patterns. However, the temperature-responsive expression patterns detected for five miRNAs by either the microarray or nCounter method were confirmed by strand-specific qRT-PCR. Of these, hsa-miR-27b and hsa-miR1260a exhibited much higher absolute expression levels, 18 and seven copies per cell, than the other three temperature-responsive miRNAs.

The mechanism by which expression levels of hsa-miR-92a-5p, hsa-miR-27a5p, hsa-miR-27b-5p, hsa-miR-1260a, and hsa-miR-181a-3p increase in hypothermic cells is not clear. It is also not certain whether the same mechanism is responsible for the increase of all five miRNAs. MicroRNA precursors are transcribed by the same machinery that transcribes mRNA (Wang et al. 2010). Some such as hsa-miR-92a are expressed as a miRNA cluster from a polycistronic gene coding for multiple miRNAs (Olive et al. 2010). The sequence for hsa-miR-1260a precursor is embedded in exon 3 of the neuroglobin gene. Mature miRNA is processed stepwise from pri-miRNAs to $\sim 70 \mathrm{nt}$ pre-miRNAs, $\sim 21 \mathrm{nt}$ miRNA duplexes with protruding $2 \mathrm{nt} 3^{\prime}$ ends, and finally to the singlestrand mature miRNA, which is incorporated into the RISC (for review, see Filipowicz et al. 2008). Several lines of evidence from our study suggest that the expression profiles of most of these temperature-responsive mature miRNAs result from altered post-transcriptional processing. Quantitative RT-PCR analysis of the opposite strands and the pre- and pri-forms for three of the temperature-sensitive mature miRNAs, hsa-miR-92a-1, hsa-miR-27a, and hsa-miR-27b showed similar expression levels at all three temperatures. The Affymetrix microarray platform showed similar levels of 1260a pre-miRNA at all three temperatures (Table 1). 

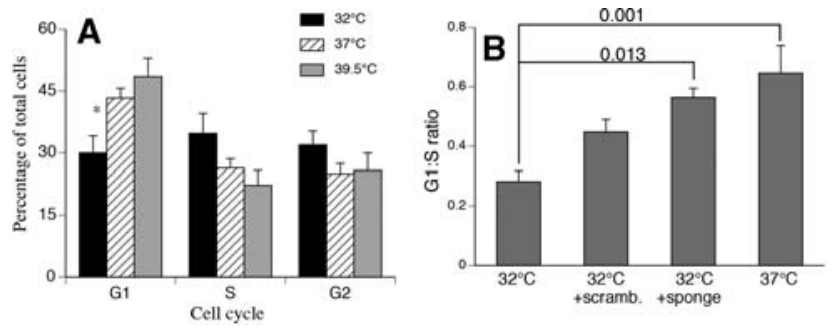

FIGURE 6. Effect of incubation temperature on cell-cycle progression. (A) Human SAECs were serum-starved for $24 \mathrm{~h}$ at $37^{\circ} \mathrm{C}$, then incubated at $32^{\circ} \mathrm{C}, 37^{\circ} \mathrm{C}$, or $39.5^{\circ} \mathrm{C}$ for an additional $24 \mathrm{~h}$ in serumcontaining growth medium, stained with propidium iodide, and the proportion of cells in G1, S, and G2 phases was determined using flow cytometry. (B) HEK 293T cells were transfected with a combination of synthetic miRNA inhibitors for hsa-miR-27b-5p, hsa-miR-1260a, and hsa-miR-92a-1-5p or an equal concentration of non-targeting scrambled control inhibitor. After $24 \mathrm{~h}$ recovery, the cells were serum-starved for $24 \mathrm{~h}$ at $37^{\circ} \mathrm{C}$, then incubated in serum-containing growth medium at $32^{\circ} \mathrm{C}$ or $37^{\circ} \mathrm{C}$ for $24 \mathrm{~h}$, and cell-cycle analysis performed and the G1:S ratio calculated. Mean \pm SEM, $n=5,\left(^{*}\right) P<0.05$ in $A$. $P$-values are indicated in $B$.

In contrast, $\mathrm{qRT}$-PCR analysis of hsa-miR-181a showed that both mature miRNA strands and the pre- and pri-forms showed a similar pattern of increased expression levels at $32^{\circ} \mathrm{C}$ and $39.5^{\circ} \mathrm{C}$ compared with $37^{\circ} \mathrm{C}$, suggesting that the temperature-dependent expression of miR-hsa-181a-3p reflected altered transcription rates.

Quantitative RT-PCR demonstrated different temperature-dependent expression profiles for the star and guide strands for three of the temperature-responsive miRNAs (Fig. 3). While the two strands of Drosophila miRNA duplexes are loaded by different Argonaute proteins (Okamura et al. 2009; Ghildiyal et al. 2010), a similar Argonaute protein-specific miRNA strand sorting mechanism has not been demonstrated in mammalian cells. Considering past studies showing that the fate of each of the two strands in the miRNA duplex is influenced by its thermodynamic stability (Khvorova et al. 2003) and its interaction with Ago2 and Dicer when complexed with trans-activation response RNA-binding protein (TRBP) or protein activator of PKR (PACT) (Noland and Doudna 2013), strand selection is an attractive candidate for a temperature-sensitive step in miRNA processing. We found that the mature duplex forms of temperature-responsive miRNAs tended to have higher predicted stability and more asymmetry in stability than other miRNAs in their respective clusters and the temperature-responsive strands represented the usually less abundant strand (Noland and Doudna 2013). However, the mechanisms for temperaturedependent strand selection, the reason for its restriction to so few miRNAs, and the extensive bias toward star strands remains incompletely understood.

The potential consequence of temperature-dependent miRNA expression for target gene expression in hypothermic and hyperthermic conditions was investigated by analyzing protein expression levels of $\mathrm{PKCa}$, which contains multi- ple predicted targets sequences for three of temperaturedependent miRNAs, hsa-miR-92a1-5p, hsa-miR-27b-5p, and hsa-miR-1260a, in its $3^{\prime}$ UTR region. We validated miRNA-binding activity of the putative miRNA-binding sites using dual luciferase vectors containing wild-type or mutated binding sites from PKCa. As animal miRNA may cause translational repression with or without mRNA decay (Brodersen and Voinnet 2009), we measured PKCa protein levels in hSAECs and HEK 293T cells exposed for $24 \mathrm{~h}$ to $32^{\circ}, 37^{\circ} \mathrm{C}$, and $39.5^{\circ} \mathrm{C}$. As expected based on the increased expression of PKCa-targeting miRNAs, $\mathrm{PKCa}$ protein levels were significantly decreased in both the $32^{\circ} \mathrm{C}$ hSAECs and $32^{\circ} \mathrm{C}$ HEK293T cells compared with $37^{\circ} \mathrm{C}$ cell cultures. Furthermore, the effect of hypothermia on PKCa protein levels in HEK 293T cells was blunted by inhibitors against the three putative $\mathrm{PKCa}$-targeting miRNAs. PKCa expression is known to be extensively regulated by miRNAs. The miRTar algorithm identified 372 miRNAs predicted to target the PRKCA 3' UTR, including three of our temperature-responsive miRNAs. PRKCA targeting by hsa-miR-200b (Wang et al. 2014), hsa-miR-216b (Deng et al. 2013), hsa-miR-203 (Wang et al. 2013), and hsa-miR-24-2* (Martin et al. 2014) have been confirmed experimentally. PKCa levels have been shown to increase with increasing levels of hsa-miR328 in A549 cells (Arora et al. 2011). PKCa has been reported to up-regulate hsa-miR-1 (Minetti et al. 2014), hsa-miR-101 (Chiang et al. 2010), and hsa-miR-15a (von Brandenstein et al. 2011). Our results show that three of the miRNAs that target PKCa are expressed at higher levels during hypothermia, which may contribute to unanticipated consequences of hypothermia exposure.

Considering that PKCa blocks G1/S and promotes G2/M transitions (Frey et al. 1992; Detjen et al. 2000; Gao et al. 2009; Poli et al. 2014), we compared cell-cycle profiles in hSAEC cells incubated for $24 \mathrm{~h}$ at $32^{\circ} \mathrm{C}, 37^{\circ} \mathrm{C}$, and $39.5^{\circ} \mathrm{C}$. Incubating hSAECs at $32^{\circ} \mathrm{C}$, which reduces $\mathrm{PKC}$ a protein levels, reduced the proportion of cells in G1 and increased the proportion in $\mathrm{S}$ phase compared with $37^{\circ} \mathrm{C}$ cells. These results are consistent with a loss of G1/S transition block that would be expected with lower PKCa levels in the $32^{\circ} \mathrm{C}$ cells. Treatment with the same miRNA inhibitors that blunted the effect of hypothermia on PKCa protein levels also mitigated the effect of hypothermia on cell-cycle progression in HEK 293T cells. Although we cannot exclude other effects of hypothermia that modify cell cycling, these data suggest that the miRNA targeting of PKCa contributes to altered cell-cycle progression of cells exposed to clinically relevant hypothermia.

In summary, we have shown that clinically relevant temperature deviations can modify expression levels of a narrow subset of miRNAs, which appear to largely reflect altered post-transcriptional processing. Three of the miRNAs that increase in hypothermic cells target PKCa with a predicted impact on cell-cycle transition. These previously unappreciated effects of temperature shifts may have important consequences in clinical hypothermic and hyperthermic states. 


\section{MATERIALS AND METHODS}

\section{Cell culture and treatment}

Primary cultured hSAECs were purchased from the ATCC and maintained in airway epithelial cell basal medium supplemented with the small airway cell growth kit (ATCC). To analyze miRNA expression, hSAECs (lot no. 58704924) isolated from a 37-yr-old Caucasian male were growth factor-starved by culturing in basal medium without growth factors for $24 \mathrm{~h}$ at $37^{\circ} \mathrm{C}$ and $5 \% \mathrm{CO}_{2}$, then incubated in basal medium with or without $1 \mathrm{ng} / \mathrm{mL}$ rhTNFa (R\&D Systems) at $32^{\circ} \mathrm{C}, 37^{\circ} \mathrm{C}$, or $39.5^{\circ} \mathrm{C}$ for $24 \mathrm{~h}$ in automatic $\mathrm{CO}_{2}$ incubators. The incubators were certified to have $<0.2^{\circ} \mathrm{C}$ temperature variation (Forma) and were calibrated for each experiment using an electronic thermometer (FLUKE Instruments model 5211). A total of five independent experiments were performed for the microarray and Nanostring nCounter assays (NanoString Technologies). Human SAECs from the original donor and a second lot of hSAECs from a 20-yr-old Caucasian female donor (lot no. 60747453) were similarly treated for confirmation of specific miRNA expression by quantitative RT-PCR. HEK 293T cells were obtained from ATCC and were maintained at $37^{\circ} \mathrm{C}$ in Dulbecco's Minimal Essential Medium (DMEM) with $4.5 \mathrm{~g} / \mathrm{L}$ glucose and supplemented with $5 \%$ fetal bovine serum (FBS).

\section{RNA extraction and RNA quality control}

Total RNA was extracted from treated cells using TRIzol (Life Technologies) as per the manufacturer's instructions. The purity and concentration of RNA samples were determined by absorbance at 260 and $280 \mathrm{~nm}$ measured using a dual beam UV spectrophotometer (Nanodrop; Thermo-Fisher Scientific) and RNA integrity was evaluated by capillary electrophoresis using the RNA 6000 Nano Lab-on-a-Chip kit and the Bioanalyzer 2100 (Agilent Technologies) as per the manufacturer's instructions. Only sets of samples with acceptable RNA quality for all six treatments were used for the miRNA analysis. MiRNA expression profiles in three of the five sets of RNA samples were analyzed by microarray hybridization. The same three sets of samples and one additional set of samples were analyzed using the Nanostring nCounter solution hybridization assay.

\section{Array hybridization and analyses}

MiRNA microarray analysis was performed by Genome Explorations. RNA was processed and labeled according to standard RT-IVT methods. Labeled cRNA $(15.0 \mu \mathrm{g})$ was fragmented by ionmediated hydrolysis and hybridized for $16 \mathrm{~h}$ at $45^{\circ} \mathrm{C}$ to Affymetrix miRNA v2.0 array. The arrays were read and the $\log _{2}$ mean intensities were used for further analysis. Data were first filtered for human miRNA and miRNA probe sets with at least one detection call among the 18 samples were included for Perform Principal Components Analysis (PCA) to identify outlier samples. One $39.5^{\circ} \mathrm{C}$ sample was identified as an extreme outlier and removed from further analysis. ANOVA was performed for all six groups (with and without Benjamini-Hochberg FDR correction). Independent $t$-tests were performed for each pairwise comparison. Data were filtered for ANOVA $P$ values $<0.05$ and an absolute $\log _{2}$ fold-change $>0.585$ (1.5-fold) and $t$-test $P$ value $<0.05$ in each pairwise comparison were selected for further validation.

\section{Nanostring nCounter assays}

A novel multiplex assay for miRNA expression was performed using nCounter miRNA Expression Assay Kits at NanoString Technologies. This method enables multiplexed direct digital counting of miRNA molecules (Geiss et al. 2008). To prepare miRNA molecules for hybridization in the nCounter assay, proprietary DNA sequences called miRtags were ligated to the mature miRNAs using bridging oligonucleotides. After ligation and purification, the tagged mature miRNAs were hybridized to color-coded reporter probes and biotinylated capture probes, immobilized onto a cartridge, and each immobilized miRNA was identified based on its color code and quantified. A total of 811 human and human-associated viral miRNAs were simultaneously assayed. All assays were performed using $100 \mathrm{ng}$ of total RNA following the standard nCounter miRNA Assay Protocol. Hybridizations were performed automatically by mixing $5 \mu \mathrm{L}$ of each miRNA multiplex assay with $20 \mu \mathrm{L}$ NanoString nCounter reporter probe mix and $5 \mu \mathrm{L}$ capture probe $\operatorname{mix}\left(30 \mu \mathrm{L}\right.$ total reaction volume), and hybridizing at $65^{\circ} \mathrm{C}$ for $18 \mathrm{~h}$. The raw miRNA counts were analyzed using the nSolver software and normalized using the top 100 normalization method. The normalized values were then subject to two-way ANOVA and individual pair wise $t$-tests. miRNA with ANOVA $P$ values $<0.05$ and fold-change $>1.5$-fold and $t$-test $P$ value $<0.05$ in each pairwise comparison were selected for further validation. The capture efficiency is $\sim 1 \%$.

\section{Real-time quantitative RT-PCR for miRNA}

Complementary DNA was prepared from total RNA and real-time quantitative PCR was performed using Taqman miRNA assays for hsa-miR-92a-1-5p, hsa-miR-27b-5p, hsa-miR-18a, and hsa-miR$1260 \mathrm{a}$ as per manufacturer's instructions. qRT-PCR for hsa-miR$1260 \mathrm{a}$ and both mature strands of hsa-miR-181a, hsa-miR-27a, hsa-miR-27b, and hsa-miR-92a, and were analyzed using (Quanta Bioscience) qscript miRNA assays. The pre-forms of hsa-miR181a, hsa-miR-27a, hsa-miR-27b, and hsa-miR-92a were analyzed using qPCR of the cDNAs prepared for each miRNA using the Quanta kit and primers designed to target pre-sequence outside the mature miRNA sequences. $C t$ values were normalized to hsamiR-23a, which was shown to be unaltered under these treatment conditions by the nCounter assay, and fold-change versus $37^{\circ} \mathrm{C}$ was calculated using the delta-delta method (Livak and Schmittgen 2001). To quantify the primary transcripts for these miRNAs RNA from the same cell lysates were reverse transcribed using commercial reverse transcriptase and oligo $(\mathrm{dT})$ primers (Promega) and primers designed to exclude pre-form sequence. The Ct values for the primary transcripts were normalized to GAPDH. The products of the Quanta qRT-PCR assays of the temperature-responsive mature miRNAs were isolated using Qiagen minElute columns, then cloned into the T-vector cloning plasmid (Promega) according to the manufacturer's protocol. Plasmids were prepared using Qiagen miniprep columns and DNA was sequenced using T7 primer (Eurofins Genomics).

\section{Estimation of absolute miRNA expression levels}

The total number of mature hsa-miR-1260a and the opposite strands of the other temperature-responsive miRNAs, hsa-miR-27a-3p, 
hsa-miR-27b-3p, hsa-miR-92a-1-3p, and hsa-miR-181a-5p, were calculated from the Nanostring data using total number of hybridization events, assuming a collection efficiency of $1 \%$ (provided by Nanostring) and a total RNA isolation yield of $20 \mu \mathrm{g}$ per million hSAECs. This method estimated let-7a-5p expression as 204 copies per hSAEC cell, which is similar to the reported let-7a-5p expression level in A549 cells of 200 copies per cell (Bakre et al. 2012).

\section{Thermodynamic analysis of temperature-responsive miRNAs}

Thermodynamic stabilities of miRNA duplex and each of its ends comprising the terminal $3 \mathrm{bp}$ and $2 \mathrm{nt} 3^{\prime}$ overhangs were calculated using nearest-neighbor methods (Mathews et al. 1999) with adjustment for the composition of the $3^{\prime}$ overhang (O'Toole et al. 2005) using University of Vienna RNAFold Program (Gruber et al. 2008). For each miRNA, the total free energy of the duplex and the free energy with either the first $5 \mathrm{nt}$ of the $5 p$ arm or $3 p$ arm forced to be unpaired was calculated. The free energy of each end was estimated by subtracting the free energy values of each terminal unpaired constraint from the total free energy. The absolute value of the difference in free energy of the two ends was calculated as a measure of thermodynamic asymmetry of the miRNA duplex.

\section{Transfection of miRNA inhibitors}

HEK 293T cells were seeded in $6 \times 35 \mathrm{~mm}$ cell culture dishes (Corning Biosciences) and transfected $24 \mathrm{~h}$ later with pEZXAM03 vector containing complementary sequence against hsamiR-92a1-5p, hsa-miR-27b-5p, and hsa-miR-1260a or scrambled sequence. Cells were incubated at $37^{\circ} \mathrm{C}$ for $24 \mathrm{~h}$ followed by incubation at $32^{\circ} \mathrm{C}, 37^{\circ} \mathrm{C}$, or $39.5^{\circ} \mathrm{C}$ for next $24 \mathrm{~h}$. Cells were lysed in RIPA at the end of $24 \mathrm{~h}$ and immunoblotting was performed as described below. A total of four independent experiments were performed.

\section{Interaction of temperature-sensitive miRNAs with PKCo 3' UTR}

A 406 nt DNA designed to include the predicted targets of temperature-sensitive miRNAs in PKCa 3' UTR was synthesized as gBlocks and cloned between XbaI and SacI sites in pMiRGLO (Promega) to generate pmirGLO-PKCa-WT. This sequence contains three predicted binding sites each for hsa-miR-27b-5p and hsa-miR-92a-1$5 \mathrm{p}$ and one binding site for hsa-miR-1260a. A control plasmid, pmirGLO-PKCa-Mut, was similarly generated in which each of the predicted miRNA targeted sequences was mutated (Fig. 5B). HEK 293T cells were transfected with a combination of synthetic miR mimics for hsa-miR-92a1-5p (50 nM), hsa-miR-27b-5p (50 nM), and hsa-miR-1260a (25 nM) or scrambled sequence (125 nM) (Sigma MISSION microRNA Mimics) and $5 \mathrm{ng}$ pmirGLO-PKCa-WT or pmirGLO-PKCa-Mut using Lipofectamine 2000 (Life Technologies). Cells were then incubated at $37^{\circ} \mathrm{C}$ for $48 \mathrm{~h}$ and lysed in Passive lysis buffer (Promega) and analyzed using a commercial dual luciferase assay (Promega) according to the manufacturer's protocol using a PerkinElmer Victor3 Multilabel Plate reader. The firefly to renilla luminescence ratio was calculated for each well and a mean luminescence ratio was calculated for each treatment group. A set of four independent experiments were performed.

\section{Analysis of PKC $\alpha$ protein expression}

Human SAECs and HEK $293 \mathrm{~T}$ cells were incubated at $32^{\circ} \mathrm{C}, 37^{\circ} \mathrm{C}$, or $39.5^{\circ} \mathrm{C}$ for $24 \mathrm{~h}$, lysed in RIPA buffer containing protease and phosphatase inhibitors, resolved by SDS-PAGE, transferred to PVDF membrane (Immobilon-FL Transfer Membrane, Millipore), blocked with Odyssey Blocking Buffer (LI-COR), probed with primary antibodies against protein kinase C (PKC)- $\alpha$ (Cell Signaling Tech. Cat\#2056S) or $\beta$-tubulin (Millipore Cat\#MAB3408) and IRDye 800CW Goat anti-Rabbit IgG, IRDye 680RD Goat antiMouse IgG (LI-COR) secondary antibodies. In some experiments, HEK 293T cells were transfected with inhibitors of hsa-miR-92a1-5p, hsa-miR-27b-5p, and hsa-miR-1260a or with controls targeted to a scrambled sequence $24 \mathrm{~h}$ prior to changing culture temperature. The bands were detected and quantified using Odyssey-CLX infrared imaging system. The density of each PKCa band was expressed as a ratio to the $\beta$-tubulin band density from the same sample and was compared with $37^{\circ} \mathrm{C}$ control for each experiment.

\section{Cell-cycle analysis by flow cytometry}

Human SAECs were cultured at $37^{\circ} \mathrm{C}$ in complete growth medium (ATCC) for $24 \mathrm{~h}$, then were growth factor-starved by culturing in basal medium (ATCC) without growth factors for next $24 \mathrm{~h}$ at $37^{\circ} \mathrm{C}$. The serum-starved cells were then either incubated in serum-free basal medium or complete growth medium containing $5 \%$ serum for an additional $24 \mathrm{~h}$ at $32^{\circ} \mathrm{C}, 37^{\circ} \mathrm{C}$, or $39.5^{\circ} \mathrm{C}$ to analyze the effects of incubation temperature on cell cycle in the presence and absence of exogenous mitogen. Cells were harvested using trypsin-EDTA, fixed in cold $70 \%$ ethanol for $1 \mathrm{~h}$ at $-20^{\circ} \mathrm{C}$, washed twice with PBS and treated with RNAse (Qiagen). The cells were then stained with Propidium Iodide at a final concentration of $200 \mathrm{ng} /$ $\mathrm{mL}$ (Sigma) and analyzed for cell cycle using a Becton-Dickinson Flow cytometer and the Watson cell-cycle algorithm in the manufacturer's FlowJo software. HEK 293T cells were transfected with miRNA inhibitors and subjected to the same cells-cycle analysis as hSAECs.

\section{Statistics}

For quantitative RT-PCR and immunoblot data, differences between treatment groups were analyzed by repeat Mann-Whitney test using JMP 9 (SAS Institute, Inc). Differences among $>2$ treatment conditions was analyzed by one-way ANOVA. In some cases we applied a post hoc Tukey's Honestly Significant Difference test. Effects of temperature and TNFa were distinguished using a twoway ANOVA.

\section{ACKNOWLEDGMENTS}

We thank Drs. Brett Hassel, Curt Civin, and Jiang-Ying Wang (University of Maryland School of Medicine) for their helpful advice, Dr. Irina Luzina (University of Maryland School of Medicine) for her technical help, and Akshay Tambe (University of California at Berkeley) for providing the computer script to 
analyze miRNA thermodynamic characteristics. The work was supported by National Institutes of Health (NIH) grants R01HL69057 and R01HL085256 and US Department of Veterans Affairs grant BX002143.

Received November 24, 2014; accepted March 15, 2015.

\section{REFERENCES}

Appenheimer MM, Girard RA, Chen Q, Wang WC, Bankert KC, Hardison J, Bain MD, Ridgley F, Sarcione EJ, Buitrago S, et al. 2007. Conservation of IL-6 trans-signaling mechanisms controlling L-selectin adhesion by fever-range thermal stress. Eur J Immunol 37: 2856-2867.

Arora S, Ranade AR, Tran NL, Nasser S, Sridhar S, Korn RL, Ross JT, Dhruv H, Foss KM, Sibenaller Z, et al. 2011. MicroRNA-328 is associated with (non-small) cell lung cancer (NSCLC) brain metastasis and mediates NSCLC migration. Int J Cancer 129: 2621-2631.

Bakre A, Mitchell P, Coleman JK, Jones LP, Saavedra G, Teng M, Tompkins SM, Tripp RA. 2012. Respiratory syncytial virus modifies microRNAs regulating host genes that affect virus replication. J Gen Virol 93: 2346-2356.

Beilin B, Shavit Y, Razumovsky J, Wolloch Y, Zeidel A, Bessler H. 1998. Effects of mild perioperative hypothermia on cellular immune responses. Anesthesiology 89: 1133-1140.

Bernard SA, Gray TW, Buist MD, Jones BM, Silvester W, Gutteridge G, Smith K. 2002. Treatment of comatose survivors of out-of-hospital cardiac arrest with induced hypothermia. $N$ Engl J Med 346: 557-563.

Billeter AT, Qadan M, Druen D, Gardner SA, The T, Polk HC Jr. 2012. Does clinically relevant temperature change miRNA and cytokine expression in whole blood? J Interferon Cytokine Res 32: 485-494.

Brodersen P, Voinnet O. 2009. Revisiting the principles of microRNA target recognition and mode of action. Nat Rev Mol Cell Biol 10: 141-148.

Cahill CM, Warerman WR, Xie Y, Auron PE, Calderwood SK. 1996. Transcriptional repression of the prointerleukin $1 \beta$ gene by heat shock factor 1. J Biol Chem 271: 24874-24879.

Cahill CM, Lin HS, Price BD, Bruce JL, Calderwood SK. 1997. Potential role of heat shock transcription factor in the expression of inflammatory cytokines. Adv Exp Med Biol 400B: 625-630.

Chen C, Xie Y, Stevenson MA, Auron PE, Calderwood SK. 1997. Heat shock factor 1 represses Ras-induced transcriptional activation of the c-fos gene. J Biol Chem 272: 26803-26806.

Chen Q, Fisher DT, Clancy KA, Gauguet JM, Wang WC, Unger E, RoseJohn S, von Andrian UH, Baumann H, Evans SS. 2006. Fever-range thermal stress promotes lymphocyte trafficking across high endothelial venules via an interleukin 6 trans-signaling mechanism. Nat Immunol 7: 1299-1308.

Chen Q, Appenheimer MM, Muhitch JB, Fisher DT, Clancy KA, Miecznikowski JC, Wang WC, Evans SS. 2009. Thermal facilitation of lymphocyte trafficking involves temporal induction of intravascular ICAM-1. Microcirculation 16: 143-158.

Chiang CW, Huang Y, Leong KW, Chen LC, Chen HC, Chen SJ, Chou CK. 2010. PKCa mediated induction of miR-101 in human hepatoma HepG2 cells. J Biomed Sci 17: 35.

Clemmer TP, Fisher CJ Jr, Bone RC, Slotman GJ, Metz CA, Thomas FO. 1992. Hypothermia in the sepsis syndrome and clinical outcome. The Methylprednisolone Severe Sepsis Study Group. Crit Care Med 20: 1395-1401.

Cooper ZA, Ghosh A, Gupta A, Maity T, Benjamin IJ, Vogel S, Hasday JD, Singh IS. 2010a. Febrile range temperature modifies cytokine gene expression in LPS-stimulated macrophages by differentially modifying $\mathrm{Nf}-\mathrm{Kb}$ recruitment to cytokine promoters. Am J Physiol Cell Physiol 298: C171-C181.

Cooper ZA, Singh IS, Hasday JD. 2010b. Febrile range temperature represses TNF- $\alpha$ gene expression in LPS-stimulated macrophages by selectively blocking recruitment of Sp1 to the TNF- $\alpha$ promoter. Cell Stress Chaperones 15: 665-673.

Deng M, Liu JF, Gu YX, Zheng GP, He ZM. 2013. miR-216b suppresses cell proliferation and invasion by targeting PKCa in nasopharyngeal carcinoma cells. Zhonghua Zhong Liu Za Zhi 35: 645-650.

Detjen KM, Brembeck FH, Welzel M, Kaiser A, Haller H, Wiedenmann B, Rosewicz S. 2000. Activation of protein kinase Ca inhibits growth of pancreatic cancer cells via p21 ${ }^{c P}{ }_{\text {-mediated }} \mathrm{G}_{1}$ arrest. J Cell Sci 113(Pt 17): 3025-3035.

Ellis GS, Carlson DE, Hester L, He JR, Bagby GJ, Singh IS, Hasday JD. 2005. G-CSF, but not corticosterone, mediates circulating neutrophilia induced by febrile-range hyperthermia. J Appl Physiol (1985) 98: 1799-1804.

Fairchild KD, Viscardi RM, Hester L, Singh IS, Hasday JD. 2000. Effects of hypothermia and hyperthermia on cytokine production by cultured human mononuclear phagocytes from adults and newborns. J Interferon Cytokine Res 20: 1049-1055.

Fairchild K, Singh I, Patel S, Drysdale BE, Viscardi RM, Hester L, Lazusky HM, Hasday JD. 2004. Hypothermia prolongs activation of NF- $\mathrm{KB}$ and augments generation of inflammatory cytokines. Am J Physiol Cell Physiol 287: C422-C431.

Fairchild KD, Singh IS, Carter HC, Hester L, Hasday JD. 2005. Hypothermia enhances phosphorylation of I $\mathrm{KB}$ kinase and prolongs nuclear localization of NF- $\kappa \mathrm{B}$ in lipopolysaccharide-activated macrophages. Am J Physiol Cell Physiol 289: C1114-C1121.

Filipowicz W, Bhattacharyya SN, Sonenberg N. 2008. Mechanisms of post-transcriptional regulation by microRNAs: Are the answers in sight? Nat Rev Genet 9: 102-114.

Fisher DT, Chen Q, Skitzki JJ, Muhitch JB, Zhou L, Appenheimer MM, Vardam TD, Weis EL, Passanese J, Wang WC, et al. 2011. IL-6 transsignaling licenses mouse and human tumor microvascular gateways for trafficking of cytotoxic T cells. J Clin Invest 121: 3846-3859.

Frey EA, Miller DS, Gullstein J, Sundan A, Bazil V, Espevik T, Finlay BB, Wright SD. 1992. Soluble CD14 participates in the response of cells to lipopolysaccharide. J Exp Med 176: 1665-1671.

Gao Q, Tan J, Ma P, Ge J, Liu Y, Sun X, Zhou L. 2009. PKC a affects cell cycle progression and proliferation in human RPE cells through the downregulation of $\mathrm{p} 27^{\mathrm{kip} 1}$. Mol Vis 15: 2683-2695.

Geiss GK, Bumgarner RE, Birditt B, Dahl T, Dowidar N, Dunaway DL, Fell HP, Ferree S, George RD, Grogan T, et al. 2008. Direct multiplexed measurement of gene expression with color-coded probe pairs. Nat Biotechnol 26: 317-325.

Ghildiyal M, Xu J, Seitz H, Weng Z, Zamore PD. 2010. Sorting of Drosophila small silencing RNAs partitions microRNA* strands into the RNA interference pathway. RNA 16: 43-56.

Gruber AR, Lorenz R, Bernhart SH, Neuböck R, Hofacker IL. 2008. The Vienna RNA websuite. Nucleic Acids Res 36: W70-W74.

Gupta A, Cooper ZA, Tulapurkar ME, Potla R, Maity T, Hasday JD, Singh IS. 2013. Toll-like receptor agonists and febrile range hyperthermia synergize to induce heat shock protein 70 expression and extracellular release. J Biol Chem 288: 2756-2766.

Hasday JD. 1996. The influence of temperature on host defenses. In Fever: basic mechanisms and management (ed. Mackowiak PA), pp. 87-116. Raven Press, New York.

Hasday JD, Garrison A, Singh IS, Standiford T, Ellis GS, Rao S, He J-R, Rice P, Frank M, Goldblum SE, et al. 2003. Febrile-range hyperthermia augments pulmonary neutrophil recruitment and amplifies pulmonary oxygen toxicity. Am J Pathol 162: 2005-2017.

Hasday JD, Shah N, Mackowiak PA, Tulapurkar M, Nagarsekar A, Singh I. 2011. Fever, hyperthermia, and the lung: It's all about context and timing. Trans Am Clin Climatol Assoc 122: 34-47.

Hopkins PM. 2011. Malignant hyperthermia: pharmacology of triggering. Br J Anaesth 107: 48-56.

Hsu JB, Chiu CM, Hsu SD, Huang WY, Chien CH, Lee TY, Huang HD. 2011. miRTar: an integrated system for identifying miRNA-target interactions in human. BMC Bioinformatics 12: 300.

The Hypothermia after Cardiac Arrest Study Group. 2002. Mild therapeutic hypothermia to improve the neurologic outcome after cardiac arrest. N Engl J Med 346: 549-556. 
Jiang Q, DeTolla L, Kalvakolanu I, Fitzgerald B, Hasday JD. 1999a. Fever upregulates expression of pyrogenic cytokines in endotoxin-challenged mice. Am J Physiol 276: R1653-R1660.

Jiang Q, DeTolla L, Van Roojien N, Singh IS, Fitzgerald B, Lipsky MM, Kane AS, Cross AS, Hasday JD. 1999b. Febrile range temperature modifies early systemic tumor necrosis factor a expression in mice challenged with bacterial endotoxin. Infect Immun 67: 1539-1546.

Jiang Q, Cross AS, Singh IS, Chem TT, Viscardi RM, Hasday JD. 2000. Febrile core temperature is essential for optimal host defense in bacterial peritonitis. Infect Immun 68: 1265-1270.

Jurkovich GJ, Greiser WB, Luterman A, Curreri PW. 1987. Hypothermia in trauma victims: an ominous predictor of survival. J Trauma 27: 1019-1024.

Kertesz M, Iovino N, Unnerstall U, Gaul U, Segal E. 2007. The role of site accessibility in microRNA target recognition. Nat Genet 39: $1278-1284$.

Khvorova A, Reynolds A, Jayasena SD. 2003. Functional siRNAs and miRNAs exhibit strand bias. Cell 115: 209-216.

Kozomara A, Griffiths-Jones S. 2014. miRBase: annotating high confidence microRNAs using deep sequencing data. Nucleic Acids Res 42: D68-D73.

Leon LR, Helwig BG. 2010. Heat stroke: role of the systemic inflammatory response. J Appl Physiol (1985) 109: 1980-1988.

Lewis BP, Burge CB, Bartel DP. 2005. Conserved seed pairing, often flanked by adenosines, indicates that thousands of human genes are microRNA targets. Cell 120: 15-20.

Lipke AB, Matute-Bello G, Herrero R, Kurahashi K, Wong VA, Mongovin SM, Martin TR. 2010. Febrile-range hyperthermia augments lipopolysaccharide-induced lung injury by a mechanism of enhanced alveolar epithelial apoptosis. J Immunol 184: 3801-3813.

Lipke AB, Matute-Bello G, Herrero R, Wong VA, Mongovin SM, Martin TR. 2011. Death receptors mediate the adverse effects of febrile-range hyperthermia on the outcome of lipopolysaccharide-induced lung injury. Am J Physiol Lung Cell Mol Physiol 301: L60-L70.

Livak KJ, Schmittgen TD. 2001. Analysis of relative gene expression data using real-time quantitative PCR and the $2(-\Delta \Delta \mathrm{C}(\mathrm{T}))$ method. Methods 25: 402-408.

Maity TK, Henry MM, Tulapurkar ME, Shah NG, Hasday JD, Singh IS. 2011. Distinct, gene-specific effect of heat shock on heat shock factor-1 recruitment and gene expression of CXC chemokine genes. Cytokine 54: 61-67.

Martin EC, Elliott S, Rhodes LV, Antoon JW, Fewell C, Zhu Y, Driver JL, Jodari-Karimi M, Taylor CW, Flemington EK, et al. 2014. Preferential star strand biogenesis of pre-miR-24-2 targets PKC- $a$ and suppresses cell survival in MCF-7 breast cancer cells. Mol Carcinog 53: 38-48.

Mathews DH, Sabina J, Zuker M, Turner DH. 1999. Expanded sequence dependence of thermodynamic parameters improves prediction of RNA secondary structure. J Mol Biol 288: 911-940.

McClung JP, Hasday JD, He JR, Montain SJ, Cheuvront SN, Sawka MN, Singh IS. 2008. Exercise-heat acclimation in humans alters baseline levels and ex vivo heat inducibility of HSP72 and HSP90 in peripheral blood mononuclear cells. Am J Physiol Regul Integr Comp Physiol 294: R185-R191.

McFadden ER Jr, Pichurko BM. 1985. Intraairway thermal profiles during exercise and hyperventilation in normal man. J Clin Invest 76: $1007-1010$.

Minetti GC, Feige JN, Bombard F, Heier A, Morvan F, Nürnberg B, Leiss V, Birnbaumer L, Glass DJ, Fornaro M. 2014. Gai2 signaling is required for skeletal muscle growth, regeneration, and satellite cell proliferation and differentiation. Mol Cell Biol 34: 619-630.

Morrison SF, Nakamura K. 2011. Central neural pathways for thermoregulation. Front Biosci (Landmark Ed) 16: 74-104.

Nagarsekar A, Greenberg RS, Shah NG, Singh IS, Hasday JD. 2008. Febrile-range hyperthermia accelerates caspase-dependent apoptosis in human neutrophils. J Immunol 181: 2636-2643.

Nagarsekar A, Tulapurkar ME, Singh IS, Atamas SP, Shah NG, Hasday JD. 2012. Hyperthermia promotes and prevents respiratory epithelial apoptosis through distinct mechanisms. Am J Respir Cell Mol Biol 47: 824-833.

Ning XH, Chen SH, Xu CS, Li L, Yao LY, Qian K, Krueger JJ, Hyyti OM, Portman MA. 2002. Hypothermic protection of the ischemic heart via alterations in apoptotic pathways as assessed by gene array analysis. J Appl Physiol (1985) 92: 2200-2207.

Noland CL, Doudna JA. 2013. Multiple sensors ensure guide strand selection in human RNAi pathways. RNA 19: 639-648.

Okamura K, Liu N, Lai EC. 2009. Distinct mechanisms for microRNA strand selection by Drosophila argonautes. Mol Cell 36: 431-444.

Olive V, Jiang I, He L. 2010. mir-17-92, a cluster of miRNAs in the midst of the cancer network. Int J Biochem Cell Biol 42: 1348-1354.

Ostberg JR, Taylor SL, Baumann H, Repasky EA. 2000. Regulatory effects of fever-range whole-body hyperthermia on the LPS-induced acute inflammatory response. J Leukoc Biol 68: 815-820.

Ostberg JR, Gellin C, Patel R, Repasky EA. 2001. Regulatory potential of fever-range whole body hyperthermia on Langerhans cells and lymphocytes in an antigen-dependent cellular immune response. $J$ Immunol 167: 2666-2670.

O'Toole AS, Miller S, Serra MJ. 2005. Stability of $3^{\prime}$ double nucleotide overhangs that model the $3^{\prime}$ ends of siRNA. RNA 11: 512-516.

Poli A, Mongiorgi S, Cocco L, Follo MY. 2014. Protein kinase C involvement in cell cycle modulation. Biochem Soc Trans 42: 1471-1476.

Qiu P, Cui X, Barochia A, Li Y, Natanson C, Eichacker PQ. 2011. The evolving experience with therapeutic TNF inhibition in sepsis: considering the potential influence of risk of death. Expert Opin Investig Drugs 20: $1555-1564$.

Reed G. 1996. Accidental hypothermia. In Fever: basic mechanisms and management (ed. Mackowiak PA), pp. 459-465. Raven Press, New York.

Rice P, Martin E, He J-R, Frank M, DeTolla L, Hester L, O’Neill T, Manka C, Benjamin I, Nagarsekar A. 2005. Febrile-range hyperthermia augments neutrophil accumulation and enhances lung injury in experimental gram-negative bacterial pneumonia. J Immunol 174: 3676-3685.

Schwarz DS, Hutvágner G, Du T, Xu Z, Aronin N, Zamore PD. 2003. Asymmetry in the assembly of the RNAi enzyme complex. Cell 115: 199-208.

Shah NG, Hasday JD. 2012. Does temperature make a difference? It depends on how hot (or cold), for how long, and in what clinical context. Crit Care Med 40: 326-327.

Shah NG, Tulapurkar ME, Damarla M, Singh IS, Goldblum SE, Shapiro P, Hasday JD. 2012. Febrile-range hyperthermia augments reversible TNF- $\alpha$-induced hyperpermeability in human microvascular lung endothelial cells. Int J Hyperthermia 28: 627-635.

Shankaran S, Laptook AR, Ehrenkranz RA, Tyson JE, McDonald SA, Donovan EF, Fanaroff AA, Poole WK, Wright LL, Higgins RD, et al. 2005. Whole-body hypothermia for neonates with hypoxic-ischemic encephalopathy. N Engl J Med 353: 1574-1584.

Singh IS, Hasday JD. 2013. Fever, hyperthermia and the heat shock response. Int J Hyperthermia 29: 423-435.

Singh IS, Viscardi RM, Kalvakolanu I, Calderwood S, Hasday JD. 2000. Inhibition of tumor necrosis factor- $\alpha$ transcription in macrophages exposed to febrile range temperature: a possible role for heat shock factor-1 as a negative transcriptional regulator. J Biol Chem 275: 9841-9848.

Singh I, He J-R, Calderwood S, Hasday J. 2002. A high affinity HSF-1 binding site in the $5^{\prime}$-untranslated region of the murine tumor necrosis factor- $\alpha$ gene is a transcriptional repressor. J Biol Chem 277: 4981-4988.

Singh IS, Gupta A, Nagarsekar A, Cooper Z, Manka C, Hester L, Benjamin IJ, He JR, Hasday JD. 2008. Heat shock co-activates interleukin-8 transcription. Am J Respir Cell Mol Biol 39: 235-242.

Sonna LA, Kuhlmeier MM, Carter HC, Hasday JD, Lilly CM, Fairchild KD. 2006. Effect of moderate hypothermia on gene expression by THP-1 cells: a DNA microarray study. Physiol Genomics 26: 91-98. 
Truettner JS, Alonso OF, Bramlett HM, Dietrich WD. 2011. Therapeutic hypothermia alters microRNA responses to traumatic brain injury in rats. J Cereb Blood Flow Metab 31: 1897-1907.

Tulapurkar ME, Asiegbu BE, Singh IS, Hasday JD. 2009. Hyperthermia in the febrile range induces HSP72 expression proportional to exposure temperature but not to HSF-1 DNA-binding activity in human lung epithelial A549 cells. Cell Stress Chaperones 14: 499-508.

Tulapurkar ME, Hasday JD, Singh IS. 2011. Prolonged exposure to hyperthermic stress augments neutrophil recruitment to lung during the post-exposure recovery period. Int J Hyperthermia 27: 717-725.

Tulapurkar ME, Almutairy EA, Shah NG, He JR, Puche AC, Shapiro P, Singh IS, Hasday JD. 2012. Febrile-range hyperthermia modifies endothelial and neutrophilic functions to promote extravasation. Am J Respir Cell Mol Biol 46: 807-814.

van Marum RJ, Wegewijs MA, Loonen AJ, Beers E. 2007. Hypothermia following antipsychotic drug use. Eur J Clin Pharmacol 63: 627-631.

Vardam TD, Zhou L, Appenheimer MM, Chen Q, Wang WC, Baumann H, Evans SS. 2007. Regulation of a lymphocyte-endothelial-IL-6 trans-signaling axis by fever-range thermal stress: hot spot of immune surveillance. Cytokine 39: 84-96.

von Brandenstein M, Depping R, Schafer E, Dienes HP, Fries JW. 2011. Protein kinase $C$ a regulates nuclear pri-microRNA 15a release as part of endothelin signaling. Biochim Biophys Acta 1813: 1793-1802.

Wang WC, Goldman LM, Schleider DM, Appenheimer MM, Subjeck JR, Repasky EA, Evans SS. 1998. Fever-range hyperthermia enhances L-selectin-dependent adhesion of lymphocytes to vascular endothelium. J Immunol 160: 961-969.

Wang G, Wang Y, Shen C, Huang YW, Huang K, Huang TH, Nephew KP, Li L, Liu Y. 2010. RNA polymerase II binding patterns reveal genomic regions involved in microRNA gene regulation. PLoS ONE 5: e13798.
Wang C, Wang X, Liang H, Wang T, Yan X, Cao M, Wang N, Zhang S, Zen K, Zhang C, et al. 2013. miR-203 inhibits cell proliferation and migration of lung cancer cells by targeting PKCa. PLOS ONE 8: e73985.

Wang Z, Humphries B, Xiao H, Jiang Y, Yang C. 2014. MicroRNA-200b suppresses arsenic-transformed cell migration by targeting protein kinase $\mathrm{C} \alpha$ and Wnt5b-protein kinase $\mathrm{C} \alpha$ positive feedback loop and inhibiting Rac1 activation. J Biol Chem 289: 18373-18386.

Webb P. 1992. Temperatures of skin, subcutaneous tissue, muscle and core in resting men in cold, comfortable and hot conditions. Eur J Appl Physiol Occup Physiol 64: 471-476.

Wilson E, Waring WS. 2007. Severe hypotension and hypothermia caused by acute ethanol toxicity. Emerg Med J 24: e7.

Xie Y, Calderwood SK. 2001. Transcriptional repression by heat shock factor 1. Curr Top Biomed Res 4: 81-88.

Xie Y, Chen C, Stevenson MA, Auron PE, Calderwood SK. 2002. Heat shock factor-1 (HSF1) represses transcription of the interleukin $1 \beta$ (IL-1 $\beta$ ) gene through physical interaction with nuclear factor of interleukin-6 (NF-IL6). J Biol Chem 277: 11802-11810.

Xie Y, Zhong R, Chen C, Calderwood SK. 2003. Heat shock factor 1 contains two functional domains that mediate transcriptional repression of the c-fos and c-fms genes. J Biol Chem 278: 4687-4698.

Zhang L, Yang M, Wang Q, Liu M, Liang Q, Zhang H, Xiao X. 2011. HSF1 regulates expression of G-CSF through the binding element for NF-IL6/CCAAT enhancer binding protein beta. Mol Cell Biochem 352: 11-17.

Zhang H, Zhang L, Yu F, Liu Y, Liang Q, Deng G, Chen G, Liu M, Xiao X. 2012. HSF1 is a transcriptional activator of IL-10 gene expression in RAW264.7 macrophages. Inflammation 35: 15581566. 

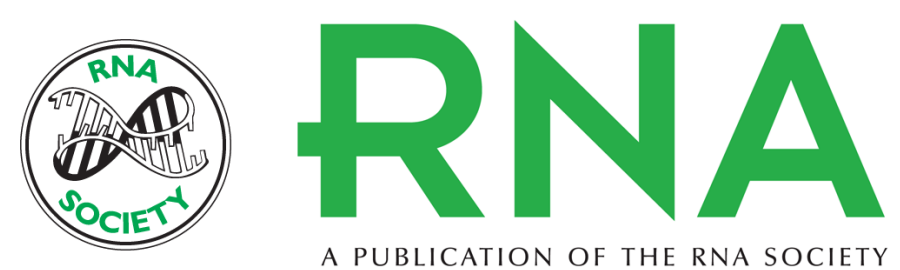

A PUBLICATION OF THE RNA SOCIETY

\section{Shifts in temperature within the physiologic range modify strand-specific expression of select human microRNAs}

Ratnakar Potla, Ishwar S. Singh, Sergei P. Atamas, et al.

RNA 2015 21: 1261-1273 originally published online May 27, 2015

Access the most recent version at doi:10.1261/rna.049122.114

References This article cites 93 articles, 23 of which can be accessed free at: http://rnajournal.cshlp.org/content/21/7/1261.full.html\#ref-list-1

Open Access Freely available online through the RNA Open Access option.

Creative This article, published in RNA, is available under a Creative Commons License

Commons (Attribution 4.0 International), as described at

License http://creativecommons.org/licenses/by/4.0/. Email Alerting $\begin{aligned} & \text { Receive free email alerts when new articles cite this article - sign up in the box at the top } \\ & \text { Service }\end{aligned}$ right corner of the article or click here. 